\title{
Continuity of care and treatment after release from prison: an urgent problem that requires solutions. The model applied in Catalonian prisons
}

\author{
Turu E, Barnés I, Marco A \\ Prison Health Programme. Institut Català de la Salut. Barcelona.
}

\begin{abstract}
Deficits in health after being released are common, and even include a higher risk of death. In these cases, the main cause of death is the use of heroin and other opioids, but there are other causes and most of them are potentially preventable. The most vulnerable groups to the increase in post-release morbidity and mortality are drug users, the mentally ill and foreign inmates from countries with fewer economic resources. What is urgently needed is to implement interventions that optimize access to health devices after prison release, avoid interruptions in the continuity of care and treatment prescribed in prison and reduce morbidity and mortality.

To achieve this, it is necessary to coordinate effective forms of care inside and outside prison and apply support measures. We present the project implemented in prisons in Catalonia, where the "liaison nurse" was used as a key figure in the process. We also present the internal and external procedure used to facilitate the transfer of sanitary and therapeutic information, to link released patients to health devices and to ensure that they are received in a timely and appropriate manner.
\end{abstract}

Keywords: prisons, health management, nurse-patient relations, morbidity, mortality.

Text received: 15/05/2019

Text accepted: 18/06/2019

\section{INTRODUCTION AND BACKGROUND}

The preliminary title of the Spanish General Public Health Act of 25 April 1986', establishes general rights for the protection of health as recognised in the Constitution, and states that all Spaniards and established foreign residents in Spain are entitled to medical care1. This law is organic, which means that it is a constitutionally necessary law to regulate specific matters, it requires a vote in favour of an absolute majority of the Congress of Deputies, it is basic and applicable throughout the State.

On the other hand, the Spanish General Prisons Act, which is also an organic law, lays down in article 4.2 that "inmates have the right to demand that that the Prison Administration should watch over their lives, physical safety and health" and it states in article 208.1 that "all inmates without exception shall be guaranteed medical/health care equivalent to that dispensed to the general public" 2 . This same principle is contained in international regulations such as the United Nations Standard Minimum Rules for the Treatment of Prisoners (also know as the Nelson Mandela rules), approved in $2015^{3}$.

It should be understood in the light of the above comments that there are national and international standards that include the right to health of the entire population and ensure that for certain conditions such as incarceration, the principle of fairness regarding this right or access to the services and benefits it guarantees are not altered, that they should be kept in conditions similar to those existing outside prison while they are incarcerated. 


\section{HEALTH SERVICES AND FAIRNESS}

It would be interesting at this point to reflect on what are regarded as "health services" and "fairness". One possible interpretation of the term is that it implies a commitment to health techniques, interventions and provisions, such as visits by professionals in the event of illness, orthopaedic or pharmaceutical provisions, access to rehabilitation, hospital admissions and a long list that includes curative and preventive activities and health promotion. But it can also be interpreted as meaning that the concept of equitable treatment should include not only the above elements, but also actions and mechanisms that guarantee continuity of care, quality control of the services provided and all those activities that in general facilitate the clinician's decision making processes, improve clinical reliability and represent more safety for the patient ${ }^{4}$. A crucial element of quality in healthcare is being able to provide a continuum in care and treatment, ensuring that the relevant clinical information about patients is available to any clinical practitioner who has to attend to or treat them. When this is applied to prison patients, not only would it be necessary to facilitate the medical and therapeutic information, but also establish links to patients that leave prison after a long sentence and make sure that the health system receives them at the appropriate time and in the right manner.

It should also be pointed out that continuity of care includes patients who, when they enter prison, did not have the right to healthcare and therefore did not have the individual national health insurance card (TSI in Spanish), which would create obstacles to them continuing to receive the treatment that commenced in prison once these persons are released, unless measures are taken to solve this situation.

For the inmate, the moment of greatest medical vulnerability is when they leave prison, for a number of reasons. Firstly, because the ex-prisoners move from a hyper-protected environment in healthcare terms to a normal one, which obliges them to take responsibility for themselves. In Catalonian prison health care, as in the Basque Country and other parts of Spain, the prison health services, unlike conventional health services outside prison, are proactive in care terms. In other words, they base their activities to a great extent on "seeking the patient" where they are offered early detection services, screening for pathologies, vaccination administration, observation of medication consumption management, adherence monitoring and long list of other activities that are absent in community health services, where the patient is responsible for his/her health. Secondly, because a large number of patients make their first contact with health resources when they enter prison and receive treatment from the prison medical services. This is sometimes because they come from pockets of marginalisation in the fourth world, with little in the way of healthy habits and little or no contact with the health services. But the main reason is that there is a large group that arrived in Spain through migratory movements and who come from foreign counties with few economic resources. $44.5 \%$ of the inmates in Catalonia are foreigners ${ }^{5}$ and $4 \%$ of the prison population do not have a TSI when they enter prison, making them a highly vulnerable group when they are released if this basic need is not met.

These considerations, in the context of an environment with financial resources and guarantees for the rights of inmates, should also include the biomedical evidence. There is evidence to suggest, for example, that health deficits after release are common, and there may even be a greater risk of death. In North Carolina (USA) ${ }^{6}$ and France 7 , higher mortality rates of $2 \%$ and $3.6 \%$ respectively, have been observed amongst ex-convicts than amongst the general public; in the French study ${ }^{7}$ this mortality was most common in the younger population, from 30 to 50 years of age.

Amongst the factors related to increased mortality after release from prison is abuse of heroin and other opiates ${ }^{8-13}$, alcohol abuse is another factor, along with treatment with antidepressants in prison or recidivism, while some other factors such as being married may act as a protective factor ${ }^{8}$. Although the main cause of death after release is from overdose, the potential causes are numerous ${ }^{6}$ and include chronic organic pathologies (cancer or heart disease), infectious diseases (such as HIV) ${ }^{14}$, or acts of violence (suicide, homicide or accidents). Many of the causes may be potentially preventable, but there is little information about the health and behaviour of the persons at risk, which makes it difficult establish evidentially-based preventive responses. However, from what little is known it can be deduced that there is an urgent need to implement interventions that reduce the increase in morbidity and mortality after release through effective coordination of healthcare and more measures to provide individual support. Some authors have pointed out ${ }^{15}$ that such coordination would involve primary healthcare as a key player in satisfying the health needs of this population, without this being the sole intervention since it would not be enough for providing truly effective support that covers every need. 


\section{THE HEALTHCARE AND THERAPEUTIC CONTINUUM: THE HIGH PRIORITY NEEDS}

The needs can be deduced from knowledge about the risk habits and morbidity of the prison population to be released. In Spain, 71\% of the inmates declare that they have consumed illegal drugs at some time in their lives, and $49 \%$, consumed them up to one month before entering prison ${ }^{16}$. In Catalonia, $5 \%$ of inmates declare that they inject illegal drugs intravenously, and according to date from the National Drugs Programme (Plan Nacional sobre Drogas ${ }^{17}$ ), there are 3,404 inmates/day $(6.7 \%$ of the total prison population) receiving treatment with methadone. The prevalence of mental disorders is also much higher amongst the prison population ${ }^{18,19}$. And as was to be expected, there is a much higher prevalence of certain infections such as latent tuberculosis infection ${ }^{5,20,21}$, HIV infection $^{5,22}$ or hepatitis B (HBV) and/or hepatitis C $(\mathrm{HCV})^{5,23}$, and others amongst the population that consume drugs and engage in other high risk practices that can lead to infection. These are therefore the major areas of morbidity that require most focus.

Some countries have implemented support programmes for inmates about to be released in order to ensure access to medical facilities, avoid interruptions in continuity of care and reduce mortality. The programmes are usually designed by the criminal justice and public health systems, or by non-governmental organisations. An example of these experiences is the Transitions Clinic Network (TCN), which seeks to improve the health of persons with chronic diseases who return to the community from prison ${ }^{24}$. However, projects of this type are usually pilot programs or experiences that are applied in a fragmented manner and are normally independent of other strategies, which often jeopardises their effectiveness. They are also usually directed solely towards special groups, like link-care 2 for homeless persons ${ }^{25}$ or the PreRelease Planning (PReP) for criminals with mental disorders ${ }^{26}$.

\section{IMPLEMENTATION OF THE LIAISON NURSE TO ENSURE THE CARE CONTINUUM IN CATALONIA}

After studying the information available in the prison and healthcare records, and the findings of the medical publications, the Prison Health Programme (Programa de Salud Penitenciaria (PSP)) of the Catalan Health Institute (ICS) came to the conclusion that activities to improve the care and therapeutic conti- nuum should be able to operate throughout the territory that they manage, and should be designed as one more activity, interrelated with the other ones run by the PSP. After studying the needs, the objectives were described, the target population was defined, the intervention programme was designed and the figure of the liaison nurse was created, who is a key part of the project, providing them with the necessary powers to fulfil their role.

\section{Objectives}

The following were established as basic objectives:

- All the inmates should have a TSI when they were released.

- All the released inmates should have, if they so required, a planned and scheduled visit programme of visits consisting of four elements: primary care, hospital care, mental health and addiction treatment.

- Community primary health care: for patients with chronic pathologies (hearts problems, diabetes, etc.), with unresolved acute processes (plaster casts, removal of stitches, etc.) or who have not completed a vaccination programme that was interrupted by release from prison.

- Hospital care: for patients receiving hospital medication dispensed for outpatients and for patients infected with HCV in any of the following situations: a) in studies prior to prescribing treatment with direct-acting antivirals (DAA); b) with unfinished DAA treatment; c) with completed DAA treatment, but awaiting checks for efficacy (sustained virological response (SVR)); d) with SVR but with a level of fibrosis that makes it recommendable to carry out regular screening of hepatocellular carcinoma.

- Mental health care (community mental health centres): for patients diagnosed with several mental illness or who maintain extensive psychiatric treatment (with three or more drugs) prior to evaluation at the mental health unit of the centre.

- Treatment for Drug Addiction (drug dependency monitoring and treatment centres): for patients receiving treatment with opioid agonists or suffering from dual pathologies that are considered to require care and control at drug addiction treatment centres.

- All the released inmates undergoing drug treatment should have a medication plan that specifies the drugs prescribed, the schedule of administration and duration of the treatment. It was 
also agreed that the prison health services should supply enough medication (for up to 15 days) to ensure continuity of treatment, until the community health services could take charge of the case.

\section{Target population}

The target population (Table 1) was considered to be the one consisting of sentenced inmates, who represent $85.4 \%$ of the prison population5, awaiting release (within 40 days) and requiring a care and/ or therapeutic continuum. Inmates were required to authorise the intervention with an informed consent, and to possess a TSI. If they did not have one, the application process was managed by the Health Administration.

The Catalonian General Directorate of Prison and Rehabilitation Services (Direcció General de Serveis Penitenciaris $i$ de Rehabilitació (DGSPiR)) provided access for the liaison nurse (LN) to enter the Justice Department's computer program to consult the list of patients in each prison with a planned release data, to enable the population suitable for intervention to be selected.

\section{Procedure}

\section{Internal procedure}

The project up to consolidation was managed by the Prison Health Programme (PHP), and was led by the person directing the nursing professionals within the programme. Implementation of the project formed part of the objectives proposed by the management of all the prison primary health care teams (PPHT). The PPHT was in turn responsible for organising and developing the project and ensuring that it was correctly implemented.

It was decided that not only the $\mathrm{LN}$ would work on the programme and that the functions would be taken on by the conventional staff of the PPHT, it was also agreed that two nurses in each PPHT would be trained specifically in the internal procedure, although recommendations were made to further extend this training to all the staff members, to enable the programme to continue without depending on one or two specially trained individuals. Then the computer processes and requirements were prepared (Figure 1) for logging onto the clinical-ECAP records (computerised clinical record program used by GPs, paediatricians and primary health care nurses of the Catalan Health Institute) ${ }^{27}$.

\section{Functions and powers of the $L N$}

The LN of each PPHT carried out a search in the computer program of the DGSPiR for inmates
Table 1. Requirements defining the "target population" of the liaison nurse intervention programme

- Sentenced inmates $(85.4 \%$ of the incarcerated population)

- Release within the next 40 days

- In need of healthcare and/or treatment

- Patient's informed consent

- TSI in force or being processed

Note. Individual medical card

in their prison who were going to be released in the next 40 days. The LN's activities included reviews (without patient) and visits (with the patient present):

a. First review: check the clinical-ECAP records to establish the needs of each patient to be released in the above mentioned period.

b. First visit: to explain the programme and its aims to the patient, agree on medical referrals, sign the informed consent and check the place of residence after release. It was important to make use of the interview to remind inmates of the importance of maintaining care and not abandoning the prescribed treatment. This visit was also used to detect any possible cases that should be excluded from the programme: 1) for expressing a wish to live outside Catalonia after release; 2) patients awaiting deportation and with a detention order for an aliens internment centre; and 3) patients referred to open prison at least five days beforehand as they were patients referred.

c. Second review: to confirm that the patient has a TSI or to process his application to the Central Registry of Insured Persons (commitment to return in 15 days) and to process the application for visits to external health centres where applicable.

d. Second visit: to provide information about the programmed plan and the location of the allocated resources and professionals, to emphasise the importance of complying with the programmed visits and review the medication plan. This visit is also used to inform the inmate that, at the time of release he shall be given an envelope with all the information prepared by the LN. The envelope includes: the TSI, a medication plan, a visits plan, a clinical report for the referred centre or centres and the medication necessary to ensure continuity for a maximum of 15 days.

e. Third review: to check if the patient has gone to the programmed visits or not and for any possible 
incidents (releases that took place before the planned date or that were not carried out, envelopes that were not delivered or not collected, return of the patient in 15 days after release, etc.).

All the reviews or visits made are recorded in the clinical-ECAP record, the information of which is then used by monitoring clinical indicators from the primary healthcare information system ((SISAP)$\mathrm{ECAP}^{27}$ (Figura 2).

\section{External procedure}

To guarantee the feasibility of the project, work was done with the management personnel of the central registry of insured persons on the procedure for certifying persons that did not have a TSI. The time spent in prison was included as time accumulated for registration in the census register for legal purposes. The programme was also presented to the Catalonian health authority, CatSalut, which issued mandatory instructions for all Catalonian healthcare organisations and bodies. This document empowered the $\mathrm{LN}$ to request a visit for patients whose release was imminent, and obliged all the hospitals, health centres, mental health centres and addiction treatment centres to facilitate a visit within 15 days after the date of release.

The DGSPiR provided whatever telephone numbers and additional computer connection points were necessary. Finally the project was presented via CatSalut to all the regional managers and persons responsible for admissions at all the health centres in Catalonia. Each one was asked to provide two contact persons for the liaison nurse: an operative and a manager, with the e-mail addresses and telephone numbers, thus providing the liaison nurses with a map of all the medical resources from which they could request a visit programme.

\section{PRELIMINARY RESULTS}

The program was implemented using a scaled approach until it was fully functional. One year on, results about the need for continuity of care in hospitals and addiction treatment centres are available for the 2,358 patients studied. Post-release hospital treatment was required for 128 cases $(5.4 \%)$ and post-release addiction treatment was needed for 146

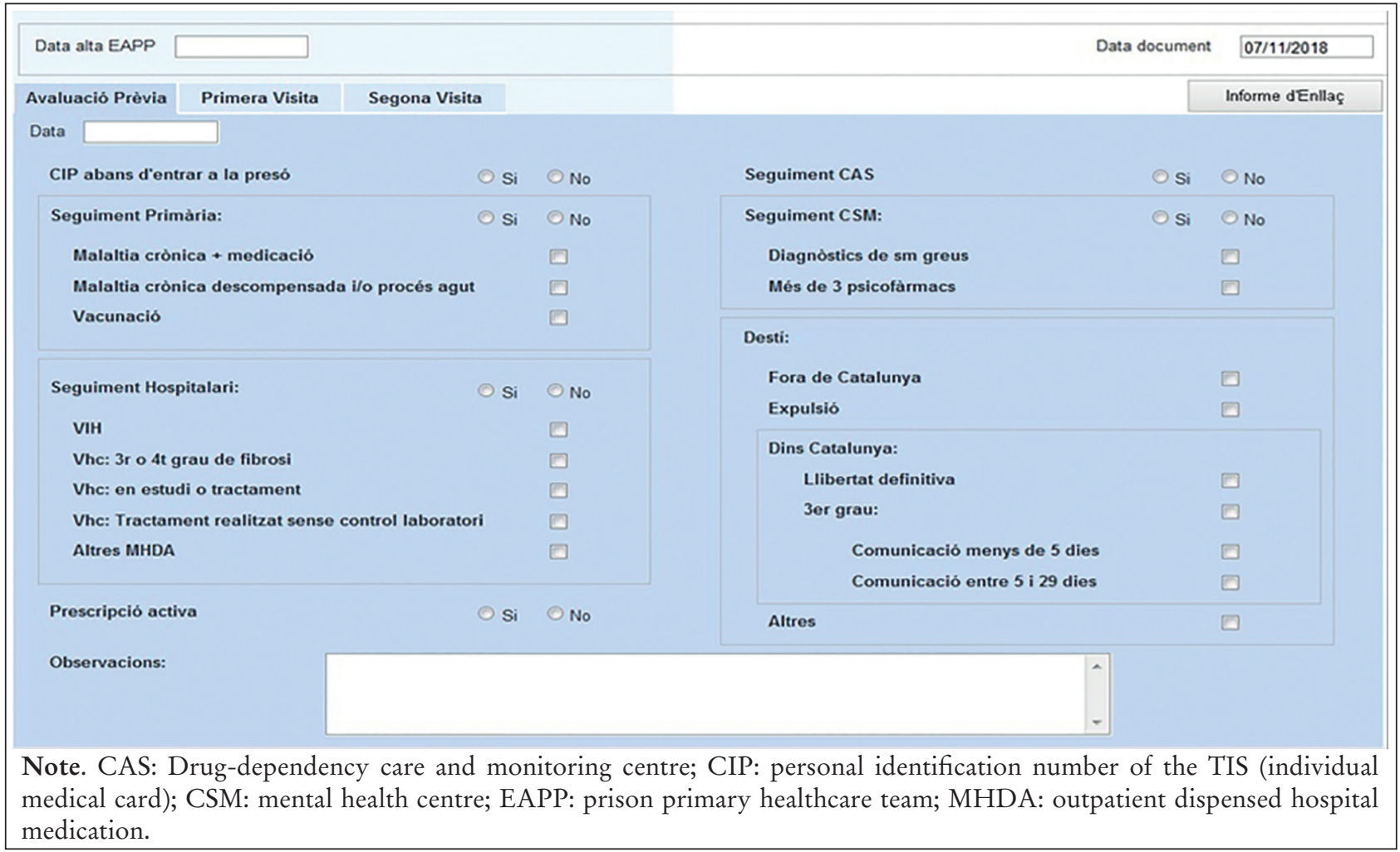

Figure 1. Graphical representation of the record sheet of the liaison nurse's activity in the clinical-ECAP record (computerised clinical record program used by general practitioners, paediatricians and primary healthcare nurses of the Catalan Health Institute). 


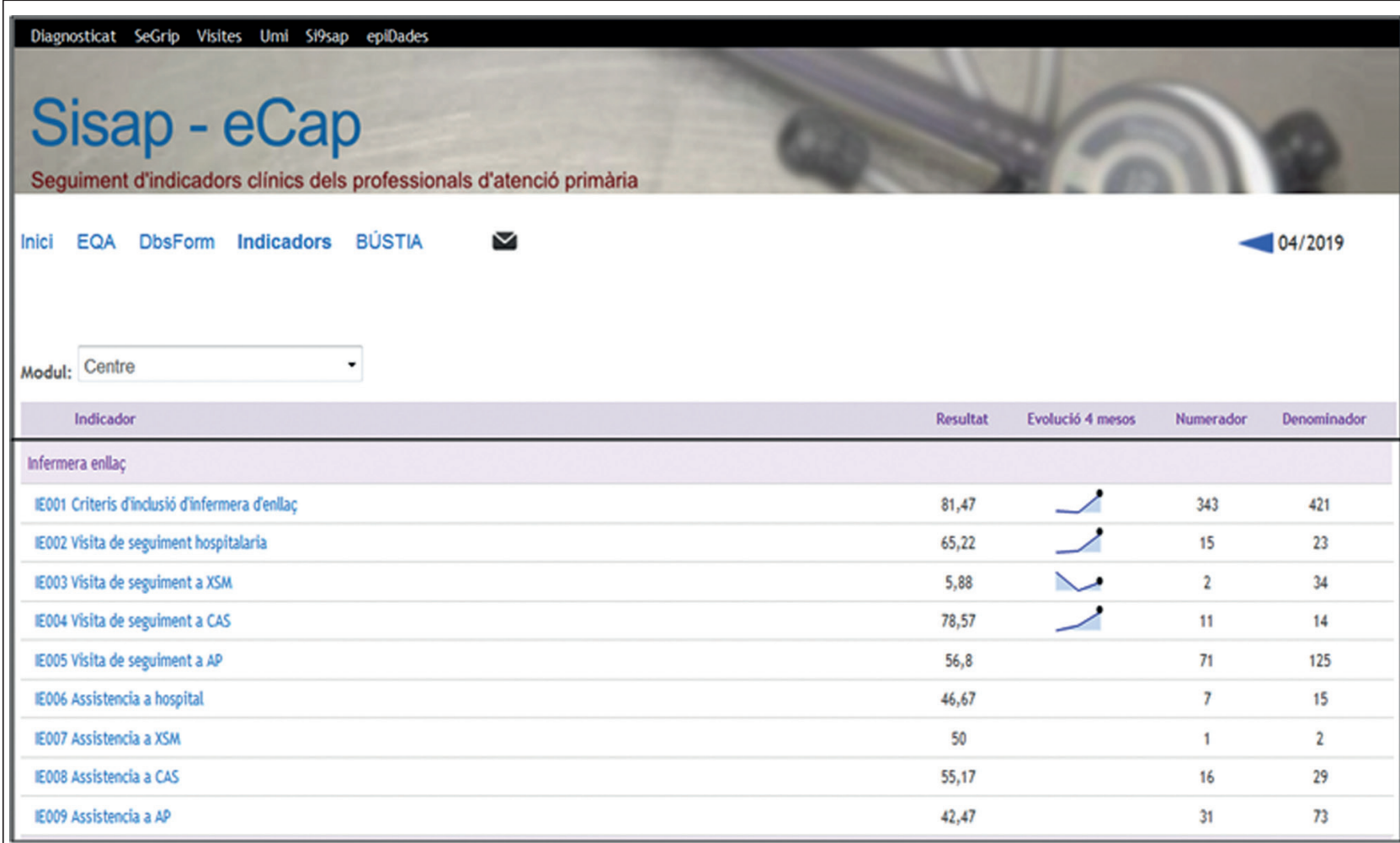

Note. AP: primary care; CAS: Drug-dependency care and monitoring centre; ECAP: computerised clinical record program used by general practitioners, paediatricians and primary healthcare nurses of the Catalan Health Institute; SISAP: primary care services information system; XSM: mental health network.

Figure 2. Graphical representation of the SISAP-ECAP (monitoring of clinical indicators of primary healthcare professionals) ${ }^{27}$.

(6.2\%). Approximately $60 \%$ of the visits required were programmed in the planned period and $70 \%$ were adequately carried out. Annual data on continuity in care for primary healthcare and mental health shall be available later this year.

\section{CONCLUSIONS AND OPPORTUNITIES FOR IMPROVEMENT}

The LNs have shown themselves to be an effective coordinating element between the prison health services and conventional health system. The preliminary data, which show a clear improvement in coordination between prisons and external services, is expected to show further improvements once the programme is fully consolidated.

It is necessary to define a preventive procedure that also fulfils this bridging function wherever possible with prison patients. At some future point care for inmates who present not only pathologies but also major risk factors may also need to be included in the procedures of the LN. These should preferably involve procedures that include detection and guarantee of continuity of care of ex-inmates with a moderate to high risk of suicide, which is currently being worked on as a high priority factor. Finally, studies should be conducted on patients awaiting release of the type and time of stay in alien internment centres. Prolonged stays at such centres would require specific agreements with the health services of the centres to ensure treatment of the incarcerated population.

\section{ACKNOWLEDGEMENTS}

We would like to express our gratitude to the liaison nurses who made this initiative possible: Roser Bautista, Núria Capella, Laura Charles, Lourdes García-González, Queralt Guixé, Helena Llavero, Maite Montilla, Mónica Pagarolas, María Esther PérezGastón, Lidia Puig, Arturo Puig, Natividad Sapera, Mireia Sellés, Edelmira Serentill, Neus Solé, Ana Cristina Varoucha and Àngels Zamora. 


\section{CORRESPONDENCE}

Elisabet Turu

Programa de Salut Penitenciària

Institut Català de la Salut

Gran Via de les Corts Catalanes, 587-589.

08004 Barcelona

E-mail: eturu@gencat.cat

\section{REFERENCES}

1. Ley Orgánica 3/1986 de 14 de abril de Medidas Especiales en Materia de Salud Pública. [Internet]. BOE. 29 Abr 1986;102:15207-24. [fecha de acceso 26 Abr 2019]. Disponible en: https://www.boe. es/boe/dias/1986/04/29/pdfs/A15207-15224.pdf

2. Ley Orgánica $1 / 1979$, de 26 de septiembre, General Penitenciaria. [Internet]. BOE. 5 Oct 1979;239. [actualizado $1 \mathrm{Jul}$ 2003]. [fecha de acceso $26 \mathrm{Abr}$ 2019]. Disponible en: https://www.boe.es/buscar/pdf/1979/BOE-A-1979-23708-consolidado. pdf

3. Naciones Unidas. 70/175. Reglas Mínimas de las Naciones Unidas para el Tratamiento de los Reclusos (Reglas Nelson Mandela). Resolución aprobada por la Asamblea General el 17 de diciembre de 2015. [Internet]. 2016. [fecha de acceso 26 Abr 2019]. Disponible en: https://www.acnur. org/fileadmin/Documentos/BDL/2016/10266. pdf?view $=1$

4. Solans O, Gallego C, Hernández-Corbacho S, García-Cuyas F, González-Quintana M, Sarquella E. HC3: la experiencia hacia la integración de la Historia Clínica en Cataluña. [Internet]. [fecha de acceso 26 Abr 2019]. Disponible en: https:// www.fundacioncaser.org/sites/default/files/laexperienciacatalana_hc3_solans_gomez_web.pdf

5. Departament de Justícia. Descriptors Estadistics Serveis Penitenciaris i Rehabilitació. [Internet]. 2019. [fecha de acceso 26 Abr 2019]. Disponible en: http://www.gencat.cat/justicia/estadistiques_ serveis_penitenciaris/

6. Jones M, Kearney GD, Xu X, Norwood T, Proescholdbell SK. Mortality Rates and Cause of Death Among Former Prison Inmates in North Carolina. N C Med J. 2017;78:223-9.

7. Désesquelles A, Kensey A. The death toll of French former prisoners. Eur J Epidemiol. 2017;32:939-41.

8. Spittal MJ, Forsyth S, Borschmann R, Young JT, Kinner SA. Modifiable risk factors for external cause mortality after release from prison: a nes- ted case-control study. Epidemiol Psychiatr Sci. 2019;28:224-33.

9. Binswanger IA, Blatchford PJ, Mueller SR, Stern MF. Mortality after prison release: opioid overdose and other causes of death, risk factors, and time trends from 1999 to 2009. Ann Intern Med. 2013;159:592-600.

10. Bukten A, Stavseth MR, Skurtveit S, Tverdal A, Strang J, Clausen T. High risk of overdose death following release from prison: variations in mortality during a 15-year observation period. Addiction. 2017;112:1432-9.

11. Chang Z, Lichtenstein P, Larsson H, Fazel S. Substance use disorders, psychiatric disorders, and mortality after release from prison: a nationwide longitudinal cohort study. Lancet Psychiatry. 2015;2:422-30.

12. Forsyth SJ, Carroll M, Lennox N, Kinner SA. Incidence and risk factors for mortality after release from prison in Australia: a prospective cohort study. Addiction. 2018;113:937-45.

13. Rosen DL, Schoenbach VJ, Wohl DA. All-cause and cause-specific mortality among men released from state prison, 1980-2005. Am J Public Health. 2008;98:2278-84.

14. Huber F, Merceron A, Madec Y, Gadio G, About V, Pastre A, et al. High mortality among male HIV-infected patients after prison release: ART is not enough after incarceration with HIV. PloS One. 2017;28;12:e0175740.

15. Kinner SA, Young JT, Carroll M. The pivotal role of primary care in meeting the health needs of people recently released from prison. Australas Psychiatry. 2015;23:650-3.

16. Encuesta sobre salud y consumo de drogas en internados en instituciones penitenciarias. ESDIP 2016. [Internet]. Ministerio de Sanidad, Servicios Sociales e Igualdad. Delegación del Gobierno para el Plan Nacional sobre Drogas; 2016. [fecha de acceso 13 Abr 2018]. Disponible en: http:// servicios.mpr.es/VisorPublicaciones/visordocumentosicopo.aspx $? \mathrm{NIPO}=680170956 \&$ SUBNI $\mathrm{PO}=0001$

17. Plan Nacional sobre Drogas. Memoria 2016. [Internet]. Delegación del Gobierno para el Plan Nacional sobre Drogas; 2016. [fecha de acceso 26 Abr 2019]. Disponible en: http://www.pnsd. mscbs.gob.es/profesionales/publicaciones/catalogo/catalogoPNSD/publicaciones/pdf/2018_ MEMORIA_2016.pdf

18. Fazel S, Seewald K. Severe mental illness in 33,588 prisoners worldwide: systematic review and metaregression analysis. Br J Psychiatry. 2012;200:364-73. 
19. Vicens E, Tort V, Dueñas RM, Muro Á, Pérez-Arnau F, Arroyo JM, et al. The prevalence of mental disorders in Spanish prisons. Crim Behav Ment Health. 2011;21:321-32.

20. García-Guerrero J, Marco A, Sáiz de la Hoya P, Vera-Remartinez EJ, Grupo PREVALHEP de prisiones. Estudio multicéntrico de prevalencia de infección tuberculosa latente en los internados en prisiones españolas. Rev Esp Sanid Penit. 2010;12:79-85.

21. Marco A, Solé N, Orcau A, Escribano M, del Baño L, Quintero S, et al. Prevalence of latent tuberculosis infection in inmates recently incarcerated in a men's prison in Barcelona. Int J Tuberc Lung Dis. 2012;16:60-4.

22. Marco A, Saiz de la Hoya P, García-Guerrero J y Grupo PREVALHEP. Estudio multicéntrico de Prevalencia de Infección por el VIH y factores asociados en las prisiones de España. Rev Esp Sanid Penit. 2012;14:19-27.

23. Saiz de la Hoya P, Marco A, García-Guerrero J, Rivera A, Prevalhep study group. Hepatitis $\mathrm{C}$ and
B prevalence in Spanish prisons. Eur J Clin Microbiol Infect Dis. 2011;30:857-62.

24. Shavit S, Aminawung JA, Birnbaum N, Greenberg S, Berthold T, Fishman A, et al. Transitions Clinic Network: Challenges And Lessons In Primary Care For People Released From Prison. Health Aff (Millwood). 2017;36:1006-15.

25. Reingle Gonzalez JM, Businelle MS, Kendzor D, Staton M, North CS, Swartz M. Using mHealth to Increase Treatment Utilization Among Recently Incarcerated Homeless Adults (Link2Care): Protocol for a Randomized Controlled Trial. JMIR Res Protoc. 2018;7:e151.

26. Smith D, Harnett S, Flanagan A, Hennessy S, Gill P, Quigley N, et al. Beyond the Walls: An Evaluation of a Pre-Release Planning (PReP) Programme for Sentenced Mentally Disordered Offenders. Front Psychiatry. 2018;9:549.

27. SI9SAP. Avisos i notificacions del SISAP. [Internet]. En: SI9SAPICS.wordpress.com. 12 Jul 2013. [fecha de acceso 12 Dic 2018]. Disponible en: https://si9sapics.wordpress.com/2013/07/12/accessos/ 